\title{
Unlocking Survival Mechanisms for Metal and Oxidative Stress in the Extremely Acidophilic, Halotolerant Acidihalobacter Genus
}

\author{
Himel Nahreen Khaleque ${ }^{1,2}$, Homayoun Fathollazadeh ${ }^{1} @$, Carolina González ${ }^{3,4}{ }^{\circledR}$, \\ Raihan Shafique ${ }^{1}$, Anna H. Kaksonen ${ }^{2}\left(0\right.$, David S. Holmes ${ }^{3,4,5}{ }^{-}$and Elizabeth L.J. Watkin $1, * \mathbb{C}$ \\ 1 School of Pharmacy and Biomedical Sciences, Curtin University, Perth 6845, Australia; \\ himelnahreen.khaleque@csiro.au (H.N.K.); homayoun.fathollahzadeh@curtin.edu.au (H.F.); \\ raihan.shafique@curtin.edu.au (R.S.) \\ 2 CSIRO Land and Water, Floreat 6014, Australia; anna.kaksonen@csiro.au \\ 3 Center for Bioinformatics and Genome Biology, Fundacion Ciencia y Vida, Santiago 7750000, Chile; \\ carola.mgr@gmail.com (C.G.); dsholmes2000@yahoo.com (D.S.H.) \\ 4 Centro de Genómica y Bioinformática, Facultad de Ciencias, Universidad Mayor, Santiago 8580000, Chile \\ 5 Universidad San Sebastian, Santiago 8320000, Chile \\ * Correspondence: E.Watkin@curtin.edu.au; Tel.: +61-8926-629-55
}

Received: 28 September 2020; Accepted: 22 November 2020; Published: 24 November 2020

\begin{abstract}
Microorganisms used for the biohydrometallurgical extraction of metals from minerals must be able to survive high levels of metal and oxidative stress found in bioleaching environments. The Acidihalobacter genus consists of four species of halotolerant, iron-sulfur-oxidizing acidophiles that are unique in their ability to tolerate chloride and acid stress while simultaneously bioleaching minerals. This paper uses bioinformatic tools to predict the genes and mechanisms used by Acidihalobacter members in their defense against a wide range of metals and oxidative stress. Analysis revealed the presence of multiple conserved mechanisms of metal tolerance. Ac. yilgarnensis $\mathrm{F}^{\mathrm{T}}{ }^{\mathrm{T}}$, the only member of this genus that oxidizes the mineral chalcopyrite, contained a $39.9 \mathrm{~Kb}$ gene cluster consisting of 40 genes encoding mobile elements and an array of proteins with direct functions in copper resistance. The analysis also revealed multiple strategies that the Acidihalobacter members can use to tolerate high levels of oxidative stress. Three of the Acidihalobacter genomes were found to contain genes encoding catalases, which are not common to acidophilic microorganisms. Of particular interest was a rubrerythrin genomic cluster containing genes that have a polyphyletic origin of stress-related functions.
\end{abstract}

Keywords: CopA; Rbr; oxidative stress; metal stress; halotolerant acidophile; bioleaching; horizontal gene transfer

\section{Introduction}

The Acidihalobacter (Ac.) genus belongs to the family Ectothiorhodospiraceae, order Chromatiales, class Gammaproteobacteria, and phylum Proteobacteria. The genus has four species, which have been validly described as Ac. ferrooxydans DSM $14175^{\mathrm{T}}$, Ac. prosperus DSM $5130^{\mathrm{T}}$, Ac. aeolianus DSM $14174^{\mathrm{T}}$

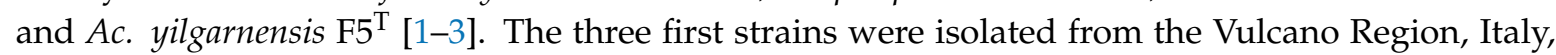
whereas Ac. yilgarnensis $\mathrm{F}^{\mathrm{T}}$ was isolated from an acidic, saline drain in the Yilgarn Region of Western Australia. All four species are aerobic, acidophilic and halotolerant, chemolithoautotrophic, and ironand sulfur-oxidizers [1-3]. A unique feature of Ac. yilgarnensis $\mathrm{F}^{\mathrm{T}}$ is its ability to leach copper from chalcopyrite under saline conditions (18 g/l chloride) [3,4]. The Acidihalobacter genus represents a novel group of microorganisms that survive in environments where other acidophiles fail to thrive. This is 
due to their ability to tolerate high levels of chloride ion simultaneously with acid stress while also bioleaching minerals [4-6].

Metals play an essential role in microorganisms as catalysts, enzyme co-factors, protein stabilizers, and electron donors or acceptors in redox processes $[7,8]$. However, bioleaching environments typically have elevated metal concentrations that can become toxic due to the accumulation of metals in cells. The toxicity effects of metals can result from the formation of coordinate bonds with anions causing blocking of functional groups of enzymes, inhibition of transport systems, displacement of essential metals from their binding sites, and disruption of cell membrane integrity [7,9]. For example, cadmium, nickel, and mercury induce the depletion of glutathione and bind to sulfhydryl groups of proteins. Arsenic has high affinity to sulfhydryl groups of proteins and may react with thiol groups of active sites in enzymes and on thioredoxin, glutathione, and glutaredoxin, and impact protein folding, intracellular redox homeostasis, and detoxification of xenobiotics [10]. The toxicity of metals varies widely depending on microbial species and strains and their strategies for exhibiting metal resistance [11]. Metal tolerance can be conveyed through the efflux of toxic metals from the cells; intra- or extracellular sequestration; enzymatic conversion of metals; exclusion of metals by a permeability barrier; and reduction in sensitivity of cellular targets [7].

Aerobic respiration of microorganisms results in the production of partially reduced reactive oxygen species (ROS), such as hydrogen peroxide $\left(\mathrm{H}_{2} \mathrm{O}_{2}\right)$, superoxide $\left(\mathrm{O}_{2} \bullet^{-}\right)$, and highly reactive hydroxyl radicals $(\mathrm{OH} \bullet)[10,12,13]$. ROS can also be generated through the exposure to environmental factors, such as light, oxidative chemical agents, metals, and minerals $[10,14]$. It has been shown that an increase in chloride stress also induces an increase of ROS in Leptospirillum ferriphilum DSM 14647 [8]. In extremely acidic bioleaching environments, ROS are generated spontaneously on the surfaces of minerals, such as pyrite [15-17]. Moreover, redox active metals, such as iron, copper, cobalt, and chromium undergo redox cycling reactions and may induce the generation of ROS [10]. Examples of metal-coupled ROS generating reactions are the Fenton (Reaction (1)) and Haber-Weiss reactions (Reactions (2) and (1), resulting in net reaction 3) $([10,18,19]$.

$$
\begin{gathered}
\mathrm{H}_{2} \mathrm{O}_{2}+\mathrm{Fe}^{2+} \rightarrow \mathrm{Fe}^{3+}+\mathrm{OH}^{-}+\mathrm{OH} \bullet \\
\mathrm{O}_{2} \bullet^{-}+\mathrm{Fe}^{3+} \rightarrow \mathrm{O}_{2}+\mathrm{Fe}^{2+} \\
\mathrm{O}_{2} \bullet^{-}+\mathrm{H}_{2} \mathrm{O}_{2} \rightarrow \mathrm{O}_{2}+\mathrm{OH}^{-}+\mathrm{OH} \bullet
\end{gathered}
$$

The ROS can cause mutations to nucleic acids, inactivate proteins, oxidize lipids, and damage other macromolecules and thus decrease cell growth and survival [19-21]. The defense mechanisms against ROS include enzymatic transformation, quenching and/or consumption of radicals to prevent ROS accumulation, repair systems for damaged macromolecules, and regulatory loops to control the expression of various response stages. The imbalance between the generation of ROS and their suppression by antioxidant defense mechanisms causes oxidative stress to cells [19]. For example, ROS promotes disulfide bond formation in proteins. Thioredoxin fold proteins (TFPs) are thought to protect damaged proteins from inactivation. Examples of TFPs include thioredoxin, peroxiredoxin, oxidoreductase, glutaredoxin, glutathione S-transferase, and glutathione peroxidase [22].

Previous proteomic studies and comparative genomics have identified mechanisms for chloride tolerance for the members of the Acidihalobacter genus; however, high levels of metal and oxidative stress also represent key factors that can compromise the feasibility of bioleaching of metals from minerals $[23,24]$. There is a limited understanding of the molecular components involved in defense mechanisms in acidophiles in general and in the recently reclassified species of the Acidihalobacter genus in particular. Furthermore, acidic brine environments, such as those found in the Yilgarn craton of Western Australia and in the Altiplano region of Northern Chile, have been suggested to be important terrestrial analogs for some Martian environments [25-28]. Therefore, uncovering the conserved mechanisms as well as evolutionary adaptations of the members of the Acidihalobacter genus can inform their effect on the bioleaching of minerals, assist in the identification of novel enzymes for 
biotechnological processes, and extend the existing theories about the boundaries of life on both Earth and in the universe [5].

\section{Materials and Methods}

\section{Genome Annotation and Comparisons}

The genome sequences of Ac. prosperus DSM 5130 (JQSG02000000) Ac. aeolianus DSM 14174 ${ }^{\mathrm{T}}$ (CP017448.1), Ac. ferrooxydans DSM 14175 (CP019434.1), and Ac. yilgarnensis F5 ${ }^{\mathrm{T}}$ (CP017415.1) were downloaded from the NCBI ftp site (ftp://ftp.ncbi.nlm.nih.gov/). For the purpose of this comparison, the genomes were annotated using the Rapid Annotation using Subsystem Technology (RAST) server (http://rast.nmpdr.org/) using the ClassicRAST annotation scheme [29]. Comparisons were performed using the SEED and RAST servers, Geneious v.10.2.6 bioinformatic software, and an in-house Python pipeline. Metabolic pathways were predicted with Kyoto Encyclopedia of Genes and Genomes (KEGG) (http://www.genome.jp/kegg/).

Mobile genetic elements (MGEs) as insertion elements, transposes, and truncated transposases in Acidihalobacter genomes were predicted with TnpPred [30]. The genome contexts of interest including metal resistance genes, hypothetical genes, and predicted mobile elements were analyzed using STRING [31], Artemis [32], and MAUVE [33]. The genome contexts were manually curated with Artemis [32] and MAUVE [33]. Synteny blocks and conservation of genetic element contexts in Acidihalobacter genomes were determined by MAUVE [33].

Genes and mechanisms involved in metal and oxidative stress resistance were identified through a literature search. Identification of similar genes in Acidihalobacter genomes was made with BLASTp and BLASTx [34] comparison using a minimal $E$-value cutoff of 1e-5, followed by a manual curation to confirm the presence of domains of interest, discarding sequences with different motifs to analyzed and truncated domains. Selected sequences were used for alignments with the MAFFT alignment tool [35,36]. Conservation of sequences domains and visualization was made with Jalview [37], WebLogo [38,39], and Aliview [40]

The copA metal-binding motifs including CXXC, HXXH, CXC, and $\mathrm{HXH}[41,42]$ were searched in the alignment of Acidihalobacter genes with copA domain. The metal-binding motifs for the copper translocating type ATPases (CXXC and CXC) identified are highlighted and represented in Figure S1.

\section{Results and Discussion}

Features of the genomes of the Acidihalobacter genus members have been described previously. In this study, further bioinformatic analyses predicted multiple genes and pathways involved in tolerance and resistance to high levels of metal and oxidative stress, which are discussed in detail below.

\subsection{Strategies to Cope with High Metal and Metalloid Concentrations}

As mentioned previously, bioleaching environments are rich in metals that can be toxic to microorganisms when they accumulate inside cells. The toxicity of metals and the mechanisms for metal resistance in bioleaching microorganisms vary widely between microbial species and strains [11]. Genome analysis revealed multiple genes and pathways that Acidihalobacter species may use to tolerate heavy metal and metalloid stresses.

\subsubsection{Copper}

Copper is an essential trace element for all aerobic organisms and functions as a cofactor in enzymes responsible for a wide variety of redox reactions. However, if copper homeostasis is not maintained, its redox properties can result in toxicity. Chalcopyrite $\left(\mathrm{CuFe}_{2} \mathrm{~S}_{2}\right)$ is the most abundant copper-containing mineral in the lithosphere and, unlike many other minerals, is recalcitrant to industrial hydrometallurgical recovery of copper (bioleaching). It has been shown by Falagán and Johnson [43] that chloride acts as a ligand for copper ions and results in the formation of both positively 
and negatively charged complexes that at low $\mathrm{pH}$ can be more toxic to cells than copper (II) or chloride ions alone. Therefore, the discovery and characterization of bacteria like Ac. yilgarnensis $\mathrm{F}^{\mathrm{T}}{ }^{\mathrm{T}}$ [6] that can tolerate low $\mathrm{pH}$ and high concentrations of chloride ion, while oxidizing chalcopyrite to release copper, is of major benefit to the biomining industry.

Several open reading frames (ORFs) have been proposed to code for putative proteins related to copper resistance in the genomes of the Acidihalobacter species, among which genes for the copper translocating P-type ATPase (copA) have been identified to have an important role [44]. It was recently noted by $\mathrm{Li}$ and $\mathrm{Zhu}$ [41] that two different types of copA genes exist which encode proteins with different substrate affinity. The P-type CopA ATPase uses ATP and binds $\mathrm{Cu}(\mathrm{I})$ for transport. It contains the $\mathrm{N}$-terminal CXXC (or $\mathrm{HXXH}$ as a variant) motif and has $\mathrm{CXC}$ as its transmembrane metal-binding motif. However, the multicopper CopA has an $\mathrm{HXH}$ as its motif and uses histidine as its metal-binding residue. Therefore, to determine the type of CopA proteins used by the members of the Acidihalobacter genus, an in-depth analysis was undertaken. The majority of CopA proteins in all Acidihalobacter members was the P-type ATPase type (Figure S1). The genes where no motifs were found (Ac. ferrooxydans DSM $14175^{T}$ peg. 1233, Ac. aeolianus DSM $14174^{T}$ peg.1366, Ac. yilgarnensis F5 ${ }^{\mathrm{T}}$ peg. 1599 , Ac. prosperus DSM $5130^{\mathrm{T}}$ peg.679 and peg.2044) were identified as multicopper oxidases. Multicopper oxidases have previously been described to have roles in the copper resistance and tolerance in other bacteria [45-47]. They are responsible for copper detoxification through the use of a variety of substrates such as phenolic compounds or siderophores, by catalyzing the single-electron oxidation of four substrate equivalents coupled with the reduction of oxygen to water $[48,49]$.

Further genome analyses revealed the presence of copper-resistance proteins, CopB, CopC, and CopD, which are known to assist in the uptake and transport of copper to the cytoplasm for subsequent sequestration or expulsion [28]. Ac. prosperus DSM $5130^{\mathrm{T}}$, Ac. aeolianus DSM $14174^{\mathrm{T}}$, and Ac. yilgarnensis $\mathrm{F}^{\mathrm{T}}$ all have the $\operatorname{cop} \mathrm{C}$ and $\operatorname{cop} \mathrm{D}$ copper uptake genes as well as the $\operatorname{cop} \mathrm{B}$ gene, whereas these genes are absent in Ac. ferrooxydans DSM $14175^{\mathrm{T}}$. Furthermore, cusA, which codes for a cation efflux pump, is also known to be involved in copper resistance in the salt-sensitive acidophile, Acidithiobacillus (A.) ferrooxidans. The gene for CusA was absent in Ac. ferrooxydans DSM $14175^{T}$, but present in Ac. yilgarnensis $\mathrm{F}^{\mathrm{T}}$ ( 6 copies), Ac. aeolianus DSM $14174^{\mathrm{T}}$ (5 copies), and Ac. prosperus DSM $5130^{\mathrm{T}}$ (3 copies).

A cluster of genes found only in Ac. yilgarnensis $\mathrm{F}^{\mathrm{T}}$ contains multiple genes ( 40) encoding heavy metal-resistance transporters, metal-binding proteins, transcriptional regulators, and efflux proteins (Figure 1). The cluster is flanked by mobile elements, including insertion sequences IS5, IS630, ISL3 families, and DUF4396 and DUF302 domain-containing proteins. An analysis of the best BLASTx hits (Table S1) of these genes suggests that most are derived from horizontal gene transfer from acidophilic bacteria, while others may have entered by vertical descent from halophilic or halotolerant common ancestors. Upon comparison with the copper tolerance genes in the other species it was observed that the copA genes were located in various regions of the genome, but were not organized as a gene cluster with other heavy metal tolerance genes. Ac. yilgarnensis $\mathrm{F}^{\mathrm{T}}$ is the only pure mesophilic, aerobic, iron-, and sulfur-oxidizing isolate of the Acidihalobacter genus which has been shown to bioleach chalcopyrite at $18 \mathrm{~g} / \mathrm{l}$ chloride ion. Here, we hypothesize that the ability of Ac. yilgarnensis $\mathrm{F}^{\mathrm{T}}$ to successfully bioleach chalcopyrite is due to the presence of the cluster of genes encoding additional proteins with roles in metal resistance. 


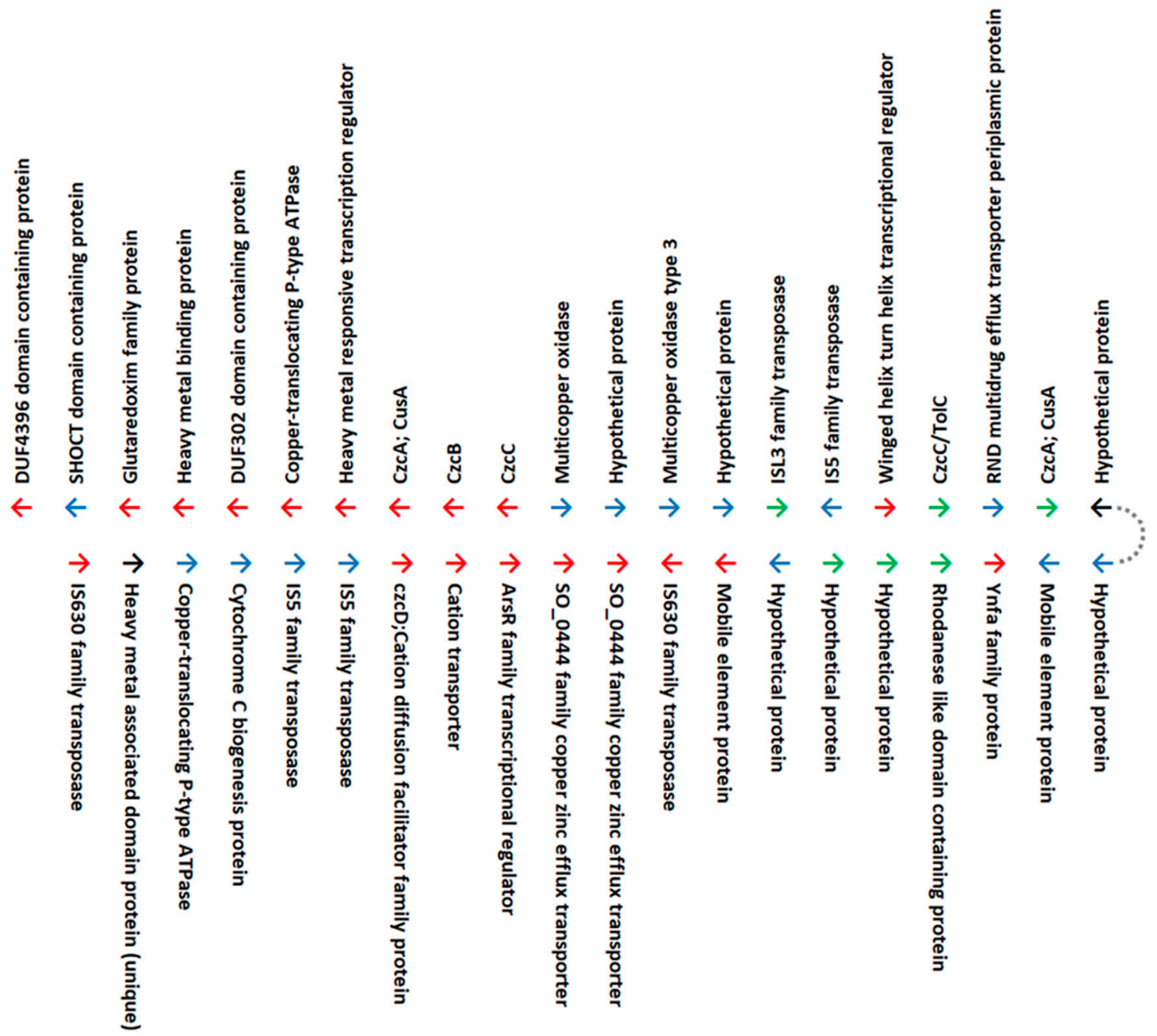

Figure 1. Region of the Acidihalobacter yilgarnensis $\mathrm{F}^{\mathrm{T}}$ identified to be rich in mobile genetic elements and copper-resistance genes. Red arrows = genes with similarity to orthologs in acidophiles; blue arrows = genes with similarity to orthologs in neutrophilic, halophilic, and halotolerant organisms or to other non-acidophiles, green arrows = genes with similarity to orthologs in halotolerant microorganisms, black arrows = genes unique to Acidihalobacter. Dotted line represents contiguity. Additional information can be found in Supplementary File 1, Table S1.

\subsubsection{Other Divalent Heavy Metals and Metalloids}

Mercury $(\mathrm{Hg})$ is amongst the most toxic heavy metals due to its high affinity binding to sulfhydryl ligands in amino acids, thereby resulting in changes in protein structure that may lead to a loss of function [50]. Mercuric reductase (MerA) is a homodimeric flavin-dependent disulfide oxidoreductase that has been identified as the central enzyme in the microbial mercury resistance system as it catalyzes the reduction of $\mathrm{Hg}(\mathrm{II})$ to volatile $\mathrm{Hg}(0)$ [51]. In addition to MerA, mer operons often encode for proteins involved in regulation (MerR, MerD), Hg scavenging/binding (MerP), and organomercury degradation (MerB), as well as one or more inner membrane scanning transport proteins (MerT, MerC, MerE, MerF, MerG) [51]. The genomes of Acidihalobacter showed differences in the organization of their mer genes. Ac. prosperus DSM $5130^{\mathrm{T}}$ and Ac. yilgarnensis $\mathrm{F}^{\mathrm{T}}$ contained a copy of merA, mer $\mathrm{P}$, and merT as part of one cluster. However, in Ac. aeolianus DSM $14174^{\mathrm{T}}$, the merP was replaced by a cation transporter. This cluster was not present in Ac. ferrooxydans DSM $14175^{\mathrm{T}}$. Additional mer gene clusters containing $m e r \mathrm{C}$, merR, and merA were identified on separate locations of the genomes in Ac. prosperus DSM $5130^{\mathrm{T}}$, Ac. ferrooxydans DSM $14175^{\mathrm{T}}$, and Ac. yilgarnensis $\mathrm{F}^{\mathrm{T}}{ }^{\mathrm{T}}$, but not in Ac. aeolianus DSM $14174^{\mathrm{T}}$. 
Arsenic is a highly toxic metalloid that exists in the environment mainly in inorganic forms, such as trivalent arsenite $(\mathrm{As}(\mathrm{III}))$ and pentavalent arsenate $(\mathrm{As}(\mathrm{V}))$. To survive in arsenic-rich environments, organisms have developed multiple metabolic strategies for its detoxification. A broad diversity of arsenic resistance system (ars) operons has been characterized in different species (14-18). However, the most extensively studied for arsenic detoxification are those that include the genes arsRBC or arsRDABC. The gene products are responsible for reducing cytoplasmic toxic $\mathrm{As}(\mathrm{V})$ to less toxic $\mathrm{As}(\mathrm{III})$ by (i) the uptake of arsenate by phosphate transporters and uptake of arsenite by aquaglyceroporins, (ii) transformation of $\mathrm{As}(\mathrm{V})$ to $\mathrm{As}(\mathrm{III})$ by arsenate reductases, and (iii) extrusion of $\mathrm{As}(\mathrm{III})$ by arsenite efflux permeases (9). Due to the presence of multiple arsenate reductase genes in the Acidihalobacter genomes, it is speculated that arsenic detoxification in this genus occurs through the aforementioned ars system. Proteomic studies performed on Ac. aeolianus DSM $14174^{\mathrm{T}}$ have shown the increase in abundance of arsenic reductase in this strain in the presence of high salt concentrations, suggesting increased detoxification when the isolate is under stress [52]. The genome of Ac. yilgarnensis $\mathrm{F}^{\mathrm{T}}$ contained 3 copies of the arsenate reductase genes; however, the remaining Acidihalobacter genomes contained 4 copies of this gene. However, in each isolate, only one of these arsenate reductase genes was present as part of the arsRBC operons consisting of an arsR family transcriptional regulator (repressor), arsB arsenic transporter/efflux pump, and ars C arsenate reductase. In Ac. aeolianus DSM $14174^{\mathrm{T}}$ and Ac. ferrooxydans DSM $14175^{\mathrm{T}}$, one of the arsenate reductases was directly upstream of a wrbA flavoprotein with known roles in oxidative stress. In Ac. ferrooxydans DSM $14175^{\mathrm{T}}$, one arsenate reductase gene was downstream of the ars $\mathrm{R}$ transcriptional regulator as well as a cadmium-induced protein.

Apart from the aforementioned tolerance genes, multiple genes for putative cation/multidrug or heavy metal efflux pumps (zinc, cadmium, lead, cobalt) and transporting ATPases were detected in all the genomes of the Acidihalobacter species, which are possibly used to export heavy metals across the membranes, as has been described previously by Dopson and Holmes [53]. Amongst these, the $c z c \mathrm{CBA}$ has been found to be essential in the expression of cobalt, zinc, cadmium, and nickel resistance [50]. Nickel transport and metabolism occurs through the high-affinity nickel transport HoxN, hydrogenase nickel incorporation protein HupN, and high-affinity nickel-transport NixA [54-56]. Multiple copies of transporter encoding genes were found in all Acidihalobacter genomes. Further study of these translocating ATPases and transporters is required to determine their specificity to different metals, but it is hypothesized that these all play an important role in the expulsion of heavy metals out of the cells.

\subsubsection{The poly-P Mechanism}

Metal ion removal in microorganisms may also be achieved through other mechanisms such as the complexation of metals with sulfate ions and the competition of metal ions and protons at low $\mathrm{pH}$ [53,57-60]. An additional mechanism for heavy metal tolerance in the Acidihalobacter species may be through the poly-P dependent mechanism, as reviewed by Navarro and von Bernath [44]. In this mechanism, acidophiles such as Acidithiobacillus ferrooxidans, A. caldus, A. thiooxidans, and the archaea Sulfolobus metallicus can synthesize and accumulate long polymers of inorganic polyphosphates (poly-P) from ATP using the enzyme polyphosphate kinase (Ppk) [61-65]. In the presence of copper, the polyphosphatase (Ppx) enzyme that breaks down poly-P is activated and this causes the release of inorganic phosphate [66]. The inorganic phosphate can then bind to metal cations in the cytoplasm and be excreted to the periplasmic space through inorganic phosphate carriers $[44,67]$. It has previously been suggested that the presence of Ppk and Ppx on the same operon can result in the co-transcription of these genes, thereby limiting the accumulation of polyphosphate [68]. This could help to rapidly release inorganic phosphate from polyphosphates for metal removal when the cells are faced with high metal stress. However, in the salt-sensitive A. ferrooxidans, it was found that the genes for Ppk and Ppx were not colocalized as a gene cluster, suggesting that the genes allow for accumulation of polyphosphate in this bacterium [68]. In the Acidihalobacter species, the genes for Ppx and Ppk were found to form part of a single gene cluster, except in Ac. ferrooxydans DSM $14175^{\mathrm{T}}$ where the 
genes were found in different locations of the genomes (Figure 2). Furthermore, Ac. ferrooxydans DSM $14175^{\mathrm{T}}$ contained a polyphosphate kinase 2 gene that was not present in the genomes of the other Acidihalobacter members. This suggests that, like A. ferrooxidans, Ac. ferrooxydans DSM $14175^{\mathrm{T}}$ is more likely to accumulate polyphosphates rather than breaking them down to release inorganic phosphates as a strategy for metal resistance as in the other Acidihalobacter members.

Ac. yilgarnensis $\mathrm{F}^{\top}$
Ac. aeolianus DSM $14174^{\top}$
Ac. prosperus DSM $5130^{\top}$
Ac. ferrooxydans DSM $14175^{\top}$

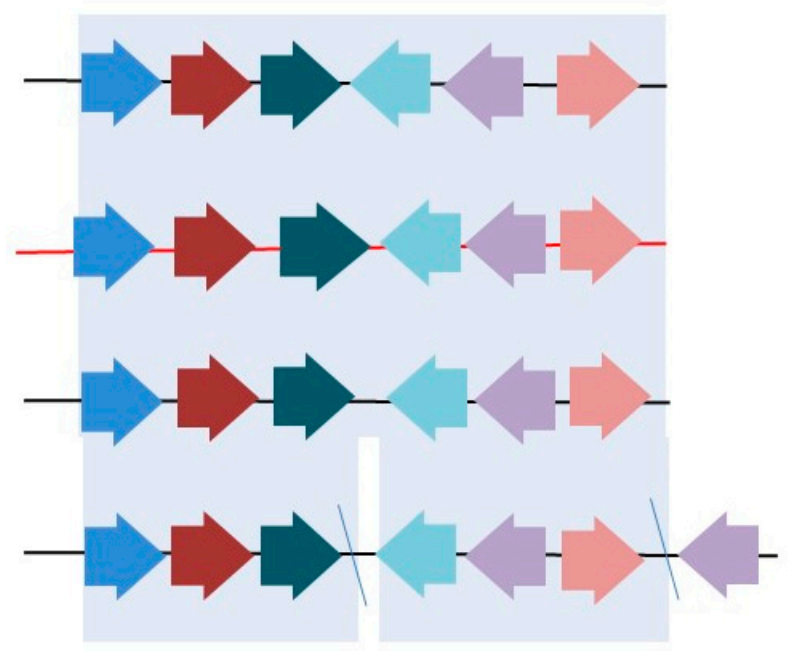

Figure 2. Genetic organization of the $p p x$ and $p p k$ genes in the four species of Acidihalobacter. Blue arrows $=$ phosphate regulon transcriptional regulatory protein $(\mathrm{PhoB})$; brown arrows = phosphate regulon sensor protein (PhoR); green arrows = exopolyphosphatase (EC 3.6.1.11) (Ppx); light blue arrows = lipoprotein, putative (Lipo); light purple arrows = polyphosphate kinase (Ppk); pink arrows = phosphate transport system regulatory protein (PhoU). Blue lines indicate that the genes are not contiguous. Red line indicates reverse orientation.

\subsection{Strategies to Tolerate Oxidative Stress}

The need for bioleaching microorganisms to maintain high oxidation rates for cellular metabolism requires them to have systems in play to protect against the direct or indirect oxidative damage caused to their DNA, proteins, and membranes by ROS species such as hydrogen peroxide, super oxide radicals, and organic peroxides $[19,69]$. As previously mentioned, both the presence of high concentrations of redox-active metals as well as chloride stress may be responsible for the generation of ROS in the Acidihalobacter species that survive in saline bioleaching environments [70]. Therefore, the genomes of the Acidihalobacter isolates were searched for predicted genes and pathways potentially involved in protection of the cells from ROS.

\subsubsection{Rubrerythrin and Neighborhood Genes}

Rbr is a member of the ferritin-like superfamily [71] and has been implicated in stress survival in many bacteria [72] and archaea [73]. It has been experimentally verified to function as a scavenger of ROS using a di-iron center to reduce $\mathrm{H}_{2} \mathrm{O}_{2}$ and organic hyperperoxide to water [74-78].

$\mathrm{Rbr}$ is found in all four species of Acidihalobacter and is located in a conserved three gene cluster that includes genes potentially encoding DUF 3501 (a protein of unknown function) and a Fe-S oxidoreductase (Figure 3). These genes have been proposed to have evolved as auxiliary functions that promote the activity of Rbr in aerobic conditions [72] (Figure 3). This association is not unexpected since Acidihalobacter are known to be aerobes [1]. The predicted domain structure of the Acidihalobacter Rbr shows that it has an RFO (rubrerythrin-associated Fe-S oxidoreductase) domain (Supplementary File 2).

In proximity to the $r b r$ gene cluster is $p r x$, predicted to encode peroxiredoxin of the Bcp-Q family, where $\mathrm{Bcp}=$ bacterioferritin comigratory protein [79] (Figure 3). The role of peroxiredoxins in the 
detoxification and removal of organic peroxides has also been described in other acidophiles, such as Sulfolobus solfataricus, Acidithiomicrobium spp., Alicyclobacillus spp., and Sulfobacillus spp. [19,80,81]. PrxBcp-Q has high peroxidase activity and broad substrate specificity, reducing peroxides such as $\mathrm{H}_{2} \mathrm{O}_{2}$, lipid peroxide, and peroxynitrite [82-87]. Nearby are genes involved in lipid and outer membrane protein formation, so it is possible that $p r x \mathrm{Bcp}-\mathrm{Q}$ is involved in a stress response to membrane components in Acidihalobacter. An alternative hypothesis is that it is involved in the reduction of the radical peroxynitrite. In low $\mathrm{pH}$ conditions, such as are found in environments inhabited by Acidihalobacter, exogenous nitrite is rapidly converted to nitrous acid which decomposes to various nitrogen oxides including nitric oxide and peroxynitrite that can diffuse through the membrane $[88,89]$. It is interesting to note that Acidihalobacter pr $x \mathrm{~B} c \mathrm{p}-\mathrm{Q}$ has significant sequence similarity to $p r \times \mathrm{B} c \mathrm{p}-\mathrm{Q}$ of moderate acidophiles belonging to the Burkholderiaceae which may reflect a function in acidic stress responses (Supplementary File 2). Nearby are several genes with potential functions in stress and $\mathrm{OMP} /$ lipid assembly. There is also a gene predicted to encode an metallo $\beta$-lactamase (MBL) fold metallo-hydrolase that is found only in Ac. ferrooxydans DSM $14175^{\mathrm{T}}$ (Figure 3). MBL fold metallo-hydrolases have diverse functions including important roles in antibiotic resistance [90]. They have also been shown to be involved in stress responses to metalloids in acidic environments and play a crucial role in tolerance to high-arsenic sulfide ore concentrates and arsenic, in particular [91]. Some are also highly mobile between species [92]. These properties could explain their presence in Ac. ferrooxydans DSM $14175^{\mathrm{T}}$. Immediately downstream of the Rbr cluster is a group of genes found only in Ac. ferrooxydans DSM $14175^{\mathrm{T}}$ (Figure 3). One of these genes is predicted to be a site-specific insertion sequence of the IS30 family with canonical DDE and DNA binding helix-turn-helix motifs (Supplementary File 2). It has strong sequence similarity to IS30 in multiple species of the extremely acidophilic Acidithiobacillus genus. Strikingly, it is more similar to IS30 sequences of the Acidithiobacillus genus than to ones in the family Ectothiorhodospiraceae, to which the Acidihalobacter genus belongs. This provides evidence for the transference by horizontal gene transfer (HGT) of IS30, and possibly also the other contiguous genes that appear in the unique insertion in Ac. ferrooxydans DSM $14175^{\mathrm{T}}$ HGT shown in Figure 3. IS30 has been shown in other organisms to be involved in environmental adaption and modification of the expression of neighboring genes at the integration site [93,94], including adaptive response to oxidative stress [95].

The contiguous genes associated with IS30 potentially encode the following proteins: (i) A transcriptional regulator of the XRE family with weak similarity to the toxin-antitoxin HipB; (ii) a site specific nuclease type II (Sma-like); (iii) a hypothetical protein with similarity to a site-specific DNA-methyltransferase; (iv) a truncated hypothetical protein with similarity to the toxin-antitoxin HipA that may function with the nearby HipB to form a toxin-antitoxin module potentially involved in the production of non-growing "persister" cells that can lie dormant during stress conditions [96], including metal and oxidative stress and perhaps other stresses. The toxin-antitoxin module has also been implicated in contact inhibition of cell growth, allowing bacteria to recognize kin cells in mixed bacterial populations [97]. Recently, it was shown that the toxin-antitoxin module can also affect membrane composition [98]. However, as a caveat, it is not known whether the truncated form of HipAB in Ac. ferrooxydans DSM $14175^{\mathrm{T}}$ is functional in any of the above roles. The site-specific nuclease type II is most similar to the restriction enzyme Sma whose DNA recognition site is an inverted repeat of six base pairs creating blunt ends on cutting that can be ligated to other blunt-ended DNA. Its activity can be inhibited by methylation of the recognition site. It is possible that the adjacent site-specific methyltransferase carries out this function. Thus, when the methylase is functioning, it protects the Ac. ferrooxydans DNA from self-damage but could potentially destroy invading non-methylated DNA such as phage and plasmids.

An analysis of the best BLASTp hits of the contiguous genes in the $r b r$ region suggests that some are most likely derived by vertical descent from non-acidophilic, halophilic, or halotolerant bacteria, while others may have entered the genome of a common ancestor by HGT, suggesting a polyphyletic origin of stress-related functions (Figure 3). 


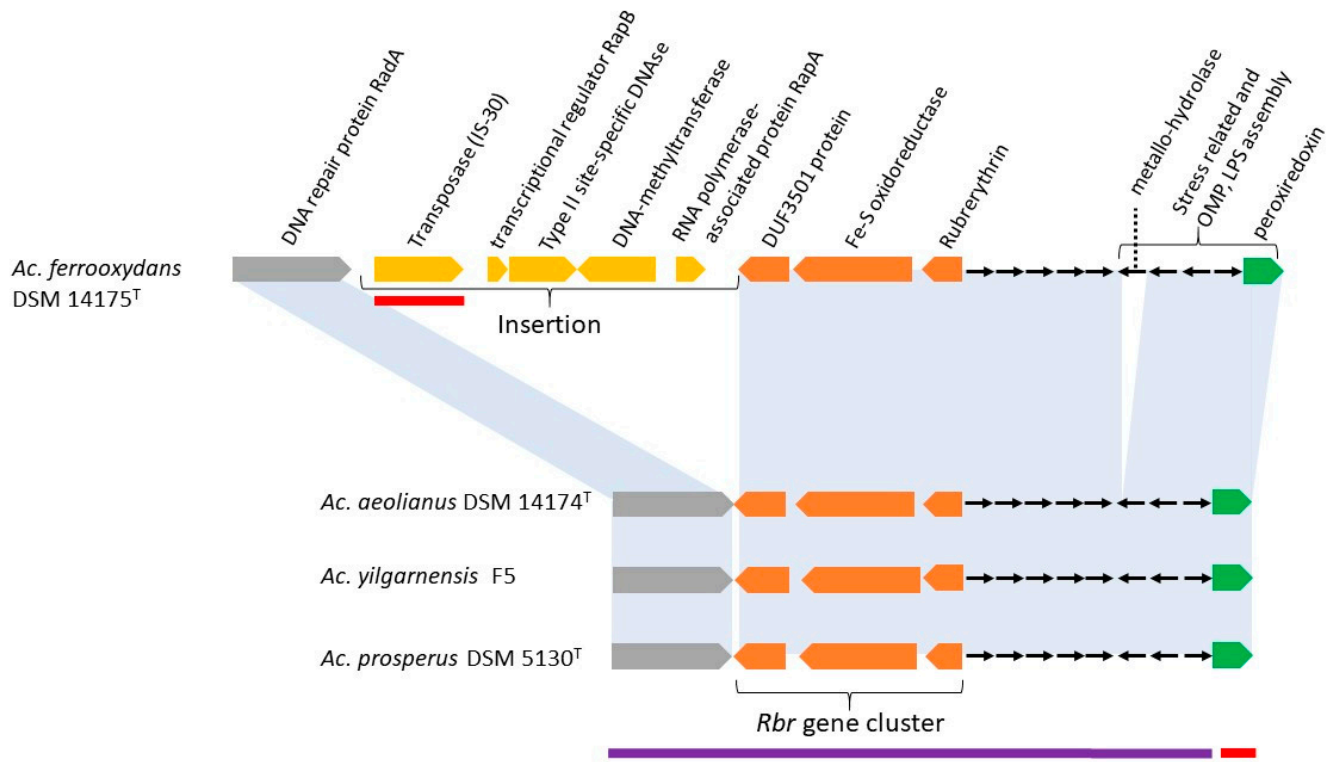

Figure 3. Genomic context of rubrerythrin $(r b r)$ and neighboring genes in the four species of Acidihalobacter. Red underlining = genes with similarity to orthologs in acidophiles; purple underlining $=$ genes with similarity to orthologs in neutrophilic halophilic and halotolerant organisms or to other non-acidophiles (Supplementary File 2).

\subsubsection{Catalase and Alkyl Hydroperoxide Reductase}

Catalase, along with superoxide dismutase and peroxidase are three of best characterized ROS defense mechanisms across domain bacteria [99]; however, comparative genomics of the oxidative stress response in forty-four bioleaching microorganisms revealed that most acidophiles lack genes encoding classical ROS consumption enzymes, particularly catalase [19]. Furthermore, multi-omics of L. ferriphilum DSM 14647 showed that homologs of catalases are absent [100]. Unexpectedly, in this study, genes encoding catalase were identified in the genomes of Ac. yilgarnensis $\mathrm{F}^{\mathrm{T}}$, Ac. prosperus DSM $5130^{\mathrm{T}}$, and Ac. ferrooxydans DSM $14175^{\mathrm{T}}$. However, homologs of the catalase genes were not found in the genome of Ac. aeolianus DSM $14174^{\mathrm{T}}$. Catalases are potentially more efficient at scavenging $\mathrm{H}_{2} \mathrm{O}_{2}$ at high concentrations [69]; therefore, their presence in Ac. yilgarnensis $\mathrm{F}^{\mathrm{T}}$, Ac. prosperus $\mathrm{DSM} 5130^{\mathrm{T}}$, and Ac. ferrooxydans DSM $14175^{\mathrm{T}}$ suggests the presence of an alternative oxidative stress mitigation strategy to promote their survival under oxidative challenges in bioleaching environments.

Upon further analysis through BLASTx, it was revealed that the sequences of the catalase genes for Ac. yilgarnensis $\mathrm{F}^{\mathrm{T}}$ and Ac. prosperus DSM $5130^{\mathrm{T}}$ were homologous (77\% protein sequence identity) to those from a novel sulfur oxidizing bacterium isolated from lake sediment, Sulfuricaulis limicola [101] (Table S2). However, the catalase gene for Ac. ferrooxydans DSM $14175^{\mathrm{T}}$ was not found to be homologous to those in the other Acidihalobacter genomes but was rather found to share $77 \%$ protein sequence similarity to catalase genes from uncultured bacteria from biostimulated petroleum-contaminated soil [102] or catalase genes from halotolerant Nitratireductor species [103,104]. Therefore, it is likely that these genes were gained from vertical transfer from a halophilic or halotolerant ancestor.

Among other genes associated with oxidative stress management during intercellular and extracellular acidification, alkyl hydroperoxide reductase subunit $\mathrm{C}(\mathrm{AhpC})$ is widely conserved in all the Acidihalobacter species. Under low stress conditions, AhpC catalyzes the reduction of endogenously generated hydrogen peroxide and organic hydroperoxides to water and alcohols $[69,105]$. The genomes of the strains Ac. yilgarnensis $\mathrm{F}^{\mathrm{T}}$ and Ac. ferrooxydans DSM $14175^{\mathrm{T}}$ each have two copies of ahpC, whereas genomes of Ac. aeolianus DSM $14174^{\mathrm{T}}$ and Ac. prosperus DSM $5130^{\mathrm{T}}$ have one copy of ahpC. It has been shown that the mutual regulation and expression of catalase and $a h p C$ genes results in dual response to oxidative stress [106]. This is consistent with previous studies that suggested proteobacteria 
have the strongest ROS defense signature across domain bacteria [23,99]. It has also been suggested that during high ROS stress in bacteria, the hydrogen peroxide-inducible genes activator protein regulator (OxyR) is activated and an increased expression and activity of the oxidative stress responses of AhpC and catalase are observed [23,107]. Genes encoding OxyR were identified in all of the Acidihalobacter species. It is perhaps more interesting to note that all of the Acidihalobacter species also contain genes encoding putative Alkanesulfonate monooxygenase (ssuD). It is likely that under sulfate starvation the ability of the SsuD to utilize alkanesulfonate was linked to oxidative stress response, with upregulation of $\operatorname{ahpC}$ and catalases to counter oxidative stress [108,109].

\subsubsection{Other Mechanisms of Oxidative Stress Tolerance}

Cell survival is largely dependent on the maintenance of disulfide states through the control of thiol/disulfide redox balance in the cytoplasm by either the thioredoxin reductase/thioredoxin system or the glutathione reductase/glutathione/glutaredoxin pathways. Both these protein systems play a large role in the defense against oxidative stress.

The thioredoxin system consists of thioredoxin reductase (TR), which regulates the intracellular redox environment through the reduction of thioredoxin (Trx) in an NADH-dependent fashion [110]. The system is involved in the regeneration of oxidative damaged proteins. It also protects against oxygen damage by modulating the activity of redox stressors and in the donation of hydrogen to detoxification enzymes that are key to the oxidative stress response [111,112]. Many studies have been performed on both aerobic and anaerobic TR/Trx systems, confirming their roles in defense against oxidative damage in both life forms and also extending the properties to reveal different types of electron donors in the different forms [113-119]. The acidophilic bacterium, L. ferriphilum DSM 14647, which can tolerate high concentrations of iron, salt, and other redox active metals, was studied for its response to oxidative stress and found to increase transcriptional activation of the genes encoding Trx and the TR enzyme, suggesting that the thioredoxin-based thiol/disulfide system plays an important role in redox protection of this isolate under extreme environmental oxidative conditions [120]. Similarly, it is likely that the Acidihalobacter species also use the TR/Trx proteins to address the challenge of oxidative stress as multiple copies of both genes were found in the genomes of all of the strains.

Genes for thiol peroxidase (Tpx) have been identified in a number of acidophilic microorganisms, including A. caldus and Sulfobacillus acidophilus [19]. Tpx is a periplasmic hydrogen peroxide scavenger, functioning as a thioredoxin system-dependent protein antioxidant [121]. The genomes of Acidihalobacter showed both thioredoxin system protein (Tpx type) as well as a bcp type. It has previously been shown in Campylobacter jejunii that the Tpx type uses only hydrogen peroxide as a substrate while the bcp-type also reduces organic peroxides [122]. Therefore, it can be assumed that the Acidihalobacter is able to use both types of substrates to help protect against oxidative stress damage.

The glutathione system, consisting of glutaredoxins (Grx), glutathione transferase (GST), glutathione reductase (GR), and NADPH, has been experimentally verified to be another important thiol-disulfide exchange system that represents the main cytoplasmic cellular redox buffer in Escherichia coli and other neutrophiles [123]. Glutaredoxins in this system are responsible for catalyzing the glutathionylation and deglutathionylation, while GST catalyzes the reduction of hydroperoxides. GR maintains the ratio of glutathione disulfide and glutathione (GSH) by using NADH to reduce the glutathione disulfide into two molecules of GSH [124,125]. Genes for the glutathione system are present on the genomes of all the Acidihalobacter spp. This includes glutathione biosynthesis genes such as glutamate-cysteine ligase, the glutathione synthase, and $\gamma$-glutamyltransferase. Furthermore, of the four families of glutaredoxins in the KEGG database-glutaredoxin 1, glutaredoxin 2, glutaredoxin 3, and monothiol glutaredoxin - the genomes of the Acidihalobacter species were found to only contain glutaredoxin 3 and the monothiol glutaredoxin but not glutaredoxin 1 . However, a glutaredoxin named GR_N was found and upon further analysis was identified as homologous to a glutathione S-transferase N-terminal domain-containing protein, which has potential roles in glutathione binding as well as glutathione transferase activity. Apart from the glutathione synthesis and glutaredoxin 
genes, there were also enzymes such as glutathione peroxidase on all the genomes of the Acidihalobacter species. These may have a role in salvaging damaged proteins and lipids, as has been described for the acidophilic Ferrovum JA12 strain [49].

Manganese-iron-type superoxide dismutase enzymes can convert superoxide radicals into hydrogen peroxide [126]. Superoxide dismutase genes are commonly found in the genomes of acidophilic microorganisms, suggesting their ability to transform superoxides $\left(\mathrm{O}_{2} \bullet-\right)$ into hydrogen peroxide $\left(\mathrm{H}_{2} \mathrm{O}_{2}\right)$ as a detoxification strategy $[12,19]$. The genome analysis of the four Acidihalobacter species showed the presence of manganese-iron-type superoxide dismutases, suggesting they use a similar detoxification strategy in their defense against damaging superoxides.

A model of the general responses to metal and oxidative stress for all Acidihalobacter species is presented in Figure 4.

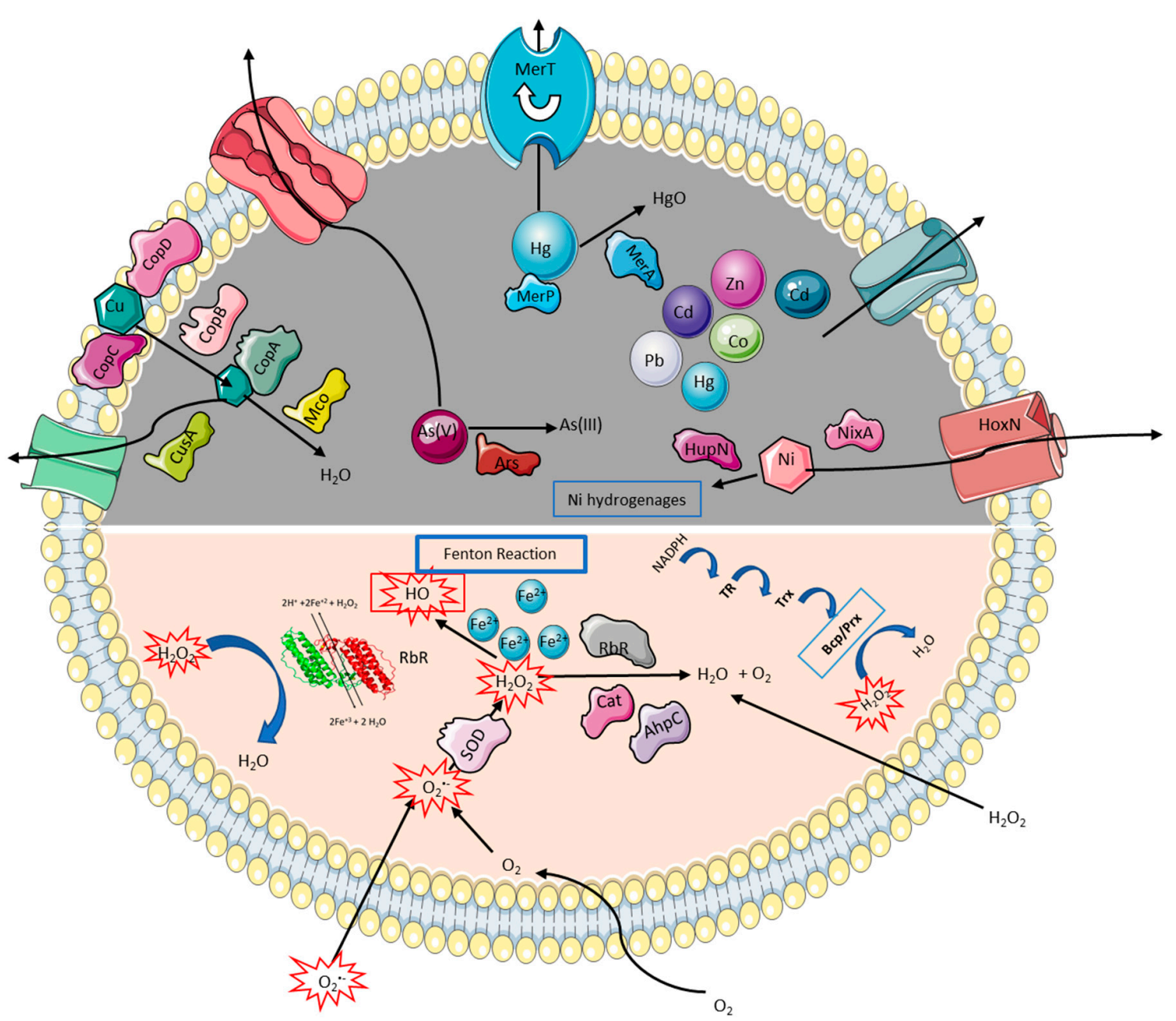

Figure 4. General model of metal (dark gray shading) and oxidative stress (pink shading) tolerance mechanisms used by all members of the Acidihalobacter genus. Alkyl hydroperoxide reductase subunit $\mathrm{C}(\mathrm{AhpC})$; arsenic resistance protein (Ars); bcp-type peroxiredoxin (BCP/Prx); catalase (Cat); copper translocating P-type ATPase (copA); copper-resistance protein B (CopB); copper-resistance protein C (CopC); copper-resistance protein $\mathrm{D}(\mathrm{CopD})$; high-affinity nickel transport protein (HoxN); hydrogenase nickel incorporation protein (HupN); high-affinity nickel-transport protein (NixA); mercuric reductase (MerA); mercury scavenging/binding (MerP); mercury transporting protein (MerT; ) multicopper oxidase (Mco); rubrerythrin (Rbr); superoxide dismutase (SOD); thioredoxin (Trx); thioredoxin reductase (TR). 


\section{Conclusions}

The genomes of the Acidihalobacter isolates contained multiple genes that have roles in tolerance to metals and oxidative stress. Some of these genes appear to have been gained through vertical gene transfer from a halophilic or halotolerant ancestor (e.g., catalase and rubrerythrin), whereas others appear to have entered an ancestral genome via horizontal gene transfer from acidophile lineages (e.g., heavy metal resistance genes). A $39.9 \mathrm{~Kb}$ DNA segment was found only in the genome of Ac. yilgarnensis $\mathrm{F}^{\mathrm{T}}{ }^{\mathrm{T}}$. This segment contains multiple copies of transposes and several copies of copper and other heavy metal associated genes. It is hypothesized that this segment confers properties that promote the bioleaching of the recalcitrant mineral chalcopyrite.

Supplementary Materials: The following are available online at http://www.mdpi.com/2073-4425/11/12/ 1392/s1, Figure S1: Identification of the metal binding motifs for potential CopA proteins in the Acidihalobacter genomes compared with copA sequences from members of Firmicutes (Bacillus subtilis), CFB group bacteria (Flavobacterium branchiophilum), Actinobacteria (Propionibacterium freudenreichii), Cyanobacteria (Synechococcus sp RCC307), Betaproteobacteria (Bordetella pertussis), Deltaproteobacteria (Geobacter sulfurreducens), Epsilonproteobacteria (Helicobacter pylori), Alphaproteobacteria (Sphingobium japonicum) and Gammaproteobacteria (Escherichia coli). Table S1: BLASTx analysis of the Acidihalobacter yilgarnensis $\mathrm{F}^{\mathrm{T}}$ operon containing mobile genetic elements and copper resistance genes. Table S2: BLASTx analysis of the sequences of the catalase genes for Ac. yilgarnensis $\mathrm{F} 5{ }^{\mathrm{T}}$, Ac. prosperus DSM $5130^{\mathrm{T}}$ and Ac. ferrooxydans DSM $14175^{\mathrm{T}}$. Homologs of the catalase genes were not found in the genome of Ac. aeolianus DSM $14174^{\mathrm{T}}$.

Author Contributions: Conceptualization, H.N.K.; methodology, H.N.K., C.G., R.S.; formal analysis, H.N.K., H.F., C.G., D.S.H.; investigation, H.N.K., C.G.; resources, D.S.H., E.L.J.W.; data curation, H.N.K., D.S.H.; writing-original draft preparation, H.N.K., H.F., A.H.K., D.S.H.; writing-review and editing, H.N.K., D.S.H., E.L.J.W., H.F.; visualization, D.S.H., H.N.K., H.F., R.S.; supervision, E.L.J.W.; project administration, E.L.J.W.; funding acquisition, E.L.J.W., D.S.H. All authors have read and agreed to the published version of the manuscript.

Funding: HNK was the recipient of an Australian Government Research Training Program Scholarship and a CSIRO Mineral Resources Postgraduate Scholarship. This research was funded by Fondecyt 1181717 and Programa de Apoyo a Centros con Financiamiento Basal AFB170004 to Fundación Ciencia \& Vida (DSH). C.G. was the recipient of a post-doctoral fellowship Fondecyt 3190792.

Conflicts of Interest: The authors declare no conflict of interest.

\section{References}

1. Khaleque, H.N.; González, C.; Kaksonen, A.H.; Boxall, N.J.; Holmes, D.S.; Watkin, E.L. Genome-based classification of two halotolerant extreme acidophiles, Acidihalobacter prosperus V6 (= DSM 14174= JCM 32253) and 'Acidihalobacter ferrooxidans' V8 (= DSM 14175= JCM 32254) as two new species, Acidihalobacter aeolianus sp. nov. and Acidihalobacter ferrooxydans sp. nov., respectively. Int. J. Syst. Evol. Microbiol. 2019, 69, 1557-1565. [PubMed]

2. Ossandon, F.J.; Cárdenas, J.P.; Corbett, M.; Quatrini, R.; Holmes, D.S.; Watkin, E.L.J.; Guo, M.-Y.; Huo, D.-Q.; Ghai, R.; Rodriguez-Valera, F.; et al. Draft Genome Sequence of the Iron-Oxidizing, Acidophilic, and Halotolerant “Thiobacillus prosperus" Type Strain DSM 5130. Genome Announc. 2014, 2, e01045-14. [CrossRef] [PubMed]

3. Khaleque, H.N.; González, C.; Johnson, D.B.; Kaksonen, A.H.; Holmes, D.S.; Watkin, E.L.J. Genome-based classification of Acidihalobacter prosperus F5 (=DSM 105917=JCM 32255) as Acidihalobacter yilgarnensis sp. nov. Int. J. Syst. Evol. Microbiol. 2020. [CrossRef] [PubMed]

4. Khaleque, H.N.; Kaksonen, A.H.; Boxall, N.J.; Watkin, E.L. Chloride ion tolerance and pyrite bioleaching capabilities of pure and mixed halotolerant, acidophilic iron- and sulfur-oxidizing cultures. Miner. Eng. 2018, 120, 87-93. [CrossRef]

5. Khaleque, H.N.; González, C.; Shafique, R.; Kaksonen, A.H.; Holmes, D.S.; Watkin, E.L.J. Uncovering the Mechanisms of Halotolerance in the Extremely Acidophilic Members of the Acidihalobacter Genus Through Comparative Genome Analysis. Front. Microbiol. 2019, 10, 155. [CrossRef] [PubMed]

6. Khaleque, H.N.; Corbett, M.K.; Ramsay, J.P.; Kaksonen, A.H.; Boxall, N.J.; Watkin, E.L. Complete genome sequence of Acidihalobacter prosperus strain F5, an extremely acidophilic, iron- and sulfur-oxidizing halophile with potential industrial applicability in saline water bioleaching of chalcopyrite. J. Biotechnol. 2017, 262, 56-59. [CrossRef] [PubMed] 
7. Dopson, M.; Baker-Austin, C.; Koppineedi, P.R.; Bond, P.L. Growth in sulfidic mineral environments: Metal resistance mechanisms in acidophilic micro-organisms. Microbiology 2003, 149, 1959-1970. [CrossRef]

8. Bruins, M.R.; Kapil, S.; Oehme, F.W. Microbial Resistance to Metals in the Environment. Ecotoxicol. Environ. Saf. 2000, 45, 198-207. [CrossRef]

9. Nies, D.H. Microbial heavy-metal resistance. Appl. Microbiol. Biotechnol. 1999, 51, 730-750. [CrossRef]

10. Ferrer, A.; Orellana, O.; Levicán, G. Oxidative Stress and Metal Tolerance in Extreme Acidophiles. Acidophiles Life Extrem. Acidic Environ. 2016, 2016, 63-76. [CrossRef]

11. Watkin, E.L.; Keeling, S.E.; Perrot, F.A.; Shiers, D.W.; Palmer, M.-L.; Watling, H.R. Metals tolerance in moderately thermophilic isolates from a spent copper sulfide heap, closely related to Acidithiobacillus caldus, Acidimicrobium ferrooxidans and Sulfobacillus thermosulfidooxidans. J. Ind. Microbiol. Biotechnol. 2009, 36, 461-465. [CrossRef] [PubMed]

12. Imlay, J.A. Pathways of Oxidative Damage. Annu. Rev. Microbiol. 2003, 57, 395-418. [CrossRef] [PubMed]

13. Imlay, J.A. Cellular Defenses against Superoxide and Hydrogen Peroxide. Annu. Rev. Biochem. 2008, 77, 755-776. [CrossRef] [PubMed]

14. Ferrer, A.; Rivera, J.; Zapata, C.; Norambuena, J.; Sandoval, Á.; Chávez, R.; Orellana, O.; Levicán, G. Cobalamin Protection against Oxidative Stress in the Acidophilic Iron-oxidizing Bacterium Leptospirillum Group II CF-1. Front. Microbiol. 2016, 7, 748. [CrossRef] [PubMed]

15. Schoonen, M.A.; Cohn, C.A.; Roemer, E.; Laffers, R.; Simon, S.R.; O’Riordan, T. Mineral-Induced Formation of Reactive Oxygen Species. Rev. Miner. Geochem. 2006, 64, 179-221. [CrossRef]

16. Schoonen, M.A.; Harrington, A.D.; Laffers, R.; Strongin, D.R. Role of hydrogen peroxide and hydroxyl radical in pyrite oxidation by molecular oxygen. Geochim. Cosmochim. Acta 2010, 74, 4971-4987. [CrossRef]

17. Jones, G.C.; Van Hille, R.P.; Harrison, S.T.L. Reactive oxygen species generated in the presence of fine pyrite particles and its implication in thermophilic mineral bioleaching. Appl. Microbiol. Biotechnol. 2012, 97, 2735-2742. [CrossRef]

18. Kehrer, J.P. The Haber-Weiss reaction and mechanisms of toxicity. Toxicology 2000, 149, 43-50. [CrossRef]

19. Cárdenas, J.P.; Moya, F.; Covarrubias, P.C.; Shmaryahu, A.; Levicán, G.; Holmes, D.S.; Quatrini, R. Comparative genomics of the oxidative stress response in bioleaching microorganisms. Hydrometallurgy 2012, 127, 162-167. [CrossRef]

20. Fridovich, I. The biology of oxygen radicals. Science 1978, 201, 875-880. [CrossRef]

21. Nordberg, J.; Arnér, E.S. Reactive oxygen species, antioxidants, and the mammalian thioredoxin system. Free Radic. Biol. Med. 2001, 31, 1287-1312. [CrossRef]

22. González, D.; Álamos, P.; Rivero, M.; Orellana, O.; Norambuena, J.; Chávez, R.; Levicán, G. Deciphering the Role of Multiple Thioredoxin Fold Proteins of Leptospirillum sp. in Oxidative Stress Tolerance. Int. J. Mol. Sci. 2020, 21, 1880. [CrossRef] [PubMed]

23. Liu, X.; Liu, H.; Wu, W.; Zhang, X.; Gu, T.; Zhu, M.; Tan, W. Oxidative Stress Induced by Metal Ions in Bioleaching of LiCoO2 by an Acidophilic Microbial Consortium. Front. Microbiol. 2020, 10, 3058. [CrossRef] [PubMed]

24. Bellenberg, S.; Huynh, D.; Poetsch, A.; Sand, W.; Vera, M. Proteomics Reveal Enhanced Oxidative Stress Responses and Metabolic Adaptation in Acidithiobacillus ferrooxidans Biofilm Cells on Pyrite. Front. Microbiol. 2019, 10, 592. [CrossRef]

25. West, M.D.; Clarke, J.D.; Laing, J.H.; Willson, D.; Waldie, J.M.; Murphy, G.M.; Thomas, M.; Mann, G. Testing technologies and strategies for exploration in Australian Mars analogues: A review. Planet. Space Sci. 2010, 58, 658-670. [CrossRef]

26. Bowen, B.B.; Benison, K.C.; Story, S.; Grotzinger, J.P.; Milliken, R.E. Early Diagenesis by Modern Acid Brines in Western Australia and Implications for the History of Sedimentary Modification on Mars. Sediment. Geol. Mars 2012, 102, 229-252. [CrossRef]

27. Quatrini, R.; Escudero, L.V.; Moya-Beltrán, A.; Galleguillos, P.A.; Issotta, F.; Acosta, M.; Cárdenas, J.P.; Nuñez, H.; Salinas, K.; Holmes, D.S.; et al. Draft genome sequence of Acidithiobacillus thiooxidans CLST isolated from the acidic hypersaline Gorbea salt flat in northern Chile. Stand. Genom. Sci. 2017, $12,84$. [CrossRef]

28. Benison, K.C. The Physical and Chemical Sedimentology of Two High-Altitude Acid Salars in Chile: Sedimentary Processes in an Extreme Environment. J. Sediment. Res. 2019, 89, 147-167. [CrossRef] 
29. Aziz, R.K.; Bartels, D.; Best, A.A.; DeJongh, M.; Disz, T.; Edwards, R.A.; Formsma, K.; Gerdes, S.; Glass, E.M.; Kubal, M.; et al. The RAST Server: Rapid Annotations using Subsystems Technology. BMC Genom. 2008, 9 , 1-15. [CrossRef]

30. Riadi, G.; Medina-Moenne, C.; Holmes, D.S. TnpPred: A Web Service for the Robust Prediction of Prokaryotic Transposases. Comp. Funct. Genom. 2012, 2012, 1-5. [CrossRef]

31. Szklarczyk, D.; Gable, A.L.; Lyon, D.; Junge, A.; Wyder, S.; Huerta-Cepas, J.; Simonovic, M.; Doncheva, N.T.; Morris, J.H.; Bork, P.; et al. STRING v11: Protein-protein association networks with increased coverage, supporting functional discovery in genome-wide experimental datasets. Nucleic Acids Res. 2019, 47, D607-D613. [CrossRef] [PubMed]

32. Carver, T.; Harris, S.R.; Berriman, M.; Parkhill, J.; McQuillan, J.A. Artemis: An integrated platform for visualization and analysis of high-throughput sequence-based experimental data. Bioinformatics 2012, 28, 464-469. [CrossRef] [PubMed]

33. Darling, A.E.; Mau, B.; Perna, N.T. progressiveMauve: Multiple Genome Alignment with Gene Gain, Loss and Rearrangement. PLoS ONE 2010, 5, e11147. [CrossRef] [PubMed]

34. Altschul, S.F.; Madden, T.L.; Schäffer, A.A.; Zhang, J.; Zhang, Z.; Miller, W.; Lipman, D.J. Gapped BLAST and PSI-BLAST: A new generation of protein database search programs. Nucleic Acids Res. 1997, 25, 3389-3402. [CrossRef] [PubMed]

35. Katoh, K. MAFFT: A novel method for rapid multiple sequence alignment based on fast Fourier transform. Nucleic Acids Res. 2002, 30, 3059-3066. [CrossRef] [PubMed]

36. Katoh, K.; Standley, D.M. MAFFT multiple sequence alignment software version 7: Improvements in performance and usability. Mol. Biol. Evol. 2013, 30, 772-780. [CrossRef] [PubMed]

37. Waterhouse, A.M.; Procter, J.B.; Martin, D.M.A.; Clamp, M.; Barton, G.J. Jalview Version 2-A multiple sequence alignment editor and analysis workbench. Bioinformatics 2009, 25, 1189-1191. [CrossRef]

38. Schneider, T.D.; Stephens, R.M. Sequence logos: A new way to display consensus sequences. Nucleic Acids Res. 1990, 18, 6097-6100. [CrossRef]

39. Crooks, G.E.; Hon, G.; Chandonia, J.-M.; Brenner, S.E. WebLogo: A Sequence Logo Generator. Genome Res. 2004, 14, 1188-1190. [CrossRef]

40. Larsson, A. AliView: A fast and lightweight alignment viewer and editor for large datasets. Bioinformatics 2014, 30, 3276-3278. [CrossRef]

41. Li, X.; Zhu, Y.-G.; Shaban, B.; Bruxner, T.J.C.; Bond, P.L.; Huang, L. Assessing the genetic diversity of Cu resistance in mine tailings through high-throughput recovery of full-length copA genes. Sci. Rep. 2015, 5, srep13258. [CrossRef] [PubMed]

42. Völlmecke, C.; Drees, S.L.; Reimann, J.; Albers, S.-V.; Lübben, M. The ATPases CopA and CopB both contribute to copper resistance of the thermoacidophilic archaeon Sulfolobus solfataricus. Microbiology 2012, 158, 1622-1633. [CrossRef] [PubMed]

43. Falagán, C.; Johnson, D.B. The significance of $\mathrm{pH}$ in dictating the relative toxicities of chloride and copper to acidophilic bacteria. Res. Microbiol. 2018, 169, 552-557. [CrossRef] [PubMed]

44. Navarro, C.A.; Von Bernath, D.; Jerez, C.A. Heavy Metal Resistance Strategies of Acidophilic Bacteria and Their Acquisition: Importance for Biomining and Bioremediation. Biol. Res. 2013, 46, 363-371. [CrossRef] [PubMed]

45. Rowland, J.L.; Niederweis, M. A Multicopper Oxidase Is Required for Copper Resistance in Mycobacterium tuberculosis. J. Bacteriol. 2013, 195, 3724-3733. [CrossRef] [PubMed]

46. Wen, Q.; Liu, X.-M.; Wang, H.; Lin, J. A versatile and efficient markerless gene disruption system forAcidithiobacillus thiooxidans: Application for characterizing a copper tolerance related multicopper oxidase gene. Environ. Microbiol. 2014, 16, 3499-3514. [CrossRef]

47. Grass, G.; Rensing, C. CueO Is a Multi-copper Oxidase That Confers Copper Tolerance in Escherichia coli. Biochem. Biophys. Res. Commun. 2001, 286, 902-908. [CrossRef]

48. Quintanar, L.; Stoj, C.; Taylor, A.B.; Hart, P.J.; Kosman, D.J.; Solomon, E.I. Shall we dance? How a multicopper oxidase chooses its electron transfer partner. Acc. Chem. Res. 2007, 40, 445-452. [CrossRef]

49. Solomon, E.I.; Sundaram, U.M.; Machonkin, T.E. Multicopper Oxidases and Oxygenases. Chem. Rev. 1996, 96, 2563-2606. [CrossRef]

50. Nies, D.H. Efflux-mediated heavy metal resistance in prokaryotes. FEMS Microbiol. Rev. 2003, 27, 313-339. [CrossRef] 
51. Boyd, E.S.; Barkay, T. The Mercury Resistance Operon: From an Origin in a Geothermal Environment to an Efficient Detoxification Machine. Front. Microbiol. 2012, 3, 349. [CrossRef] [PubMed]

52. Khaleque, H.N.; Shafique, R.; Kaksonen, A.H.; Boxall, N.J.; Watkin, E.L. Quantitative proteomics using SWATH-MS identifies mechanisms of chloride tolerance in the halophilic acidophile Acidihalobacter prosperus DSM 14174. Res. Microbiol. 2018, 169, 638-648. [CrossRef] [PubMed]

53. Dopson, M.; Holmes, D.S. Metal resistance in acidophilic microorganisms and its significance for biotechnologies. Appl. Microbiol. Biotechnol. 2014, 98, 8133-8144. [CrossRef] [PubMed]

54. Fulkerson, J.F.; Mobley, H.L.T. Membrane Topology of the NixA Nickel Transporter ofHelicobacter pylori: Two Nickel Transport-Specific Motifs within Transmembrane Helices II and III. J. Bacteriol. 2000, 182, 1722-1730. [CrossRef]

55. Degen, O.; Kobayashi, M.; Shimizu, S.; Eitinger, T. Selective transport of divalent cations by transition metal permeases: The Alcaligenes eutrophus HoxN and the Rhodococcus rhodochrous NhlF. Arch. Microbiol. 1999, 171, 139-145. [CrossRef]

56. Bartels, F.; Fernández, S.; Holtel, A.; Timmis, K.N.; De Lorenzo, V. The Essential HupB and HupN Proteins ofPseudomonas putidaProvide Redundant and Nonspecific DNA-bending Functions. J. Biol. Chem. 2001, 276, 16641-16648. [CrossRef]

57. Soboh, B.; Pinske, C.; Kuhns, M.; Waclawek, M.; Ihling, C.; Trchounian, A.; Trchounian, A.; Sinz, A.; Sawers, R.G. The respiratory molybdo-selenoprotein formate dehydrogenases of Escherichia coli have hydrogen: Benzyl viologen oxidoreductase activity. BMC Microbiol. 2011, 11, 173. [CrossRef]

58. Baker-Austin, C.; Dopson, M. Life in acid: pH homeostasis in acidophiles. Trends Microbiol. 2007, 15, $165-171$. [CrossRef]

59. Heijerick, D.; De Schamphelaere, K.; Janssen, C. Biotic ligand model development predicting Zn toxicity to the alga Pseudokirchneriella subcapitata: Possibilities and limitations. Comp. Biochem. Physiol. Part C Toxicol. Pharmacol. 2002, 133, 207-218. [CrossRef]

60. Ullrich, S.R.; Poehlein, A.; Tischler, J.S.; González, C.; Ossandon, F.J.; Daniel, R.; Holmes, D.S.; Schlömann, M.; Mühling, M. Genome Analysis of the Biotechnologically Relevant Acidophilic Iron Oxidising Strain JA12 Indicates Phylogenetic and Metabolic Diversity within the Novel Genus "Ferrovum". PLoS ONE 2016, 11, e0146832. [CrossRef]

61. Orell, A.; Navarro, C.A.; Arancibia, R.; Mobarec, J.C.; Jerez, C.A. Life in blue: Copper resistance mechanisms of bacteria and Archaea used in industrial biomining of minerals. Biotechnol. Adv. 2010, 28, 839-848. [CrossRef] [PubMed]

62. Orell, A.; Navarro, C.A.; Rivero, M.; Aguilar, J.S.; Jerez, C.A. Inorganic polyphosphates in extremophiles and their possible functions. Extremophiles 2012, 16, 573-583. [CrossRef]

63. Rao, N.N.; Gómez-García, M.R.; Kornberg, A. Inorganic Polyphosphate: Essential for Growth and Survival. Annu. Rev. Biochem. 2009, 78, 605-647. [CrossRef] [PubMed]

64. Keasling, J.D. Regulation of Intracellular Toxic Metals and Other Cations by Hydrolysis of Polyphosphate. Ann. N. Y. Acad. Sci. 1997, 829, 242-249. [CrossRef] [PubMed]

65. Orell, A.; Remonsellez, F.; Arancibia, R.; Jerez, C.A. Molecular Characterization of Copper and Cadmium Resistance Determinants in the Biomining Thermoacidophilic ArchaeonSulfolobus metallicus. Archaea 2013, 2013, 1-16. [CrossRef] [PubMed]

66. Alvarez, S.; Jerez, C.A. Copper Ions Stimulate Polyphosphate Degradation and Phosphate Efflux in Acidithiobacillus ferrooxidans. Appl. Environ. Microbiol. 2004, 70, 5177-5182. [CrossRef] [PubMed]

67. Navarro, C.A.; Orellana, L.H.; Mauriaca, C.; Jerez, C.A. Transcriptional and Functional Studies of Acidithiobacillus ferrooxidans Genes Related to Survival in the Presence of Copper. Appl. Environ. Microbiol. 2009, 75, 6102-6109. [CrossRef]

68. Fathollahzadeh, H.; Hackett, M.J.; Khaleque, H.N.; Eksteen, J.; Kaksonen, A.H.; Watkin, E.L.J. Better together: Potential of co-culture microorganisms to enhance bioleaching of rare earth elements from monazite. Bioresour. Technol. Rep. 2018, 3, 109-118. [CrossRef]

69. Imlay, J.A. The molecular mechanisms and physiological consequences of oxidative stress: Lessons from a model bacterium. Nat. Rev. Microbiol. 2013, 11, 443-454. [CrossRef]

70. Rivera Araya, J.I. Characterization of $\mathrm{NaCl}$ Tolerance Mechanism and Its Relation with the Antioxidant Mechanisms in the Acidophilic Bacterium Leptospirillum ferriphilum DSM 14647. Ph.D. Thesis, Universidad de Chile, Santiago, Chile, 2019. 
71. Andrews, S.C. The Ferritin-like superfamily: Evolution of the biological iron storeman from a rubrerythrin-like ancestor. Biochim. Biophys. Acta (BBA) Gen. Subj. 2010, 1800, 691-705. [CrossRef]

72. Cardenas, J.P.; Quatrini, R.; Holmes, D.S. Aerobic Lineage of the Oxidative Stress Response Protein Rubrerythrin Emerged in an Ancient Microaerobic, (Hyper)Thermophilic Environment. Front. Microbiol. 2016, 7, 1822. [CrossRef] [PubMed]

73. Pedone, E.; Fiorentino, G.; Bartolucci, S.; Limauro, D. Enzymatic Antioxidant Signatures in Hyperthermophilic Archaea. Antioxidants 2020, 9, 703. [CrossRef] [PubMed]

74. Coulter, E.D.; Shenvi, N.V.; Beharry, Z.M.; Smith, J.J.; Prickril, B.C.; Kurtz, N.M. Rubrerythrin-catalyzed substrate oxidation by dioxygen and hydrogen peroxide. Inorg. Chim. Acta 2000, 297, 231-241. [CrossRef]

75. Weinberg, M.V.; Jenney, F.E.; Cui, X.; Adams, M.W.W. Rubrerythrin from the Hyperthermophilic Archaeon Pyrococcus furiosus is a Rubredoxin-Dependent, Iron-Containing Peroxidase. J. Bacteriol. 2004, 186, 7888-7895. [CrossRef]

76. Mishra, S.; Imlay, J. Why do bacteria use so many enzymes to scavenge hydrogen peroxide? Arch. Biochem. Biophys. 2012, 525, 145-160. [CrossRef]

77. Martins, M.C.; Romão, C.V.; Folgosa, F.; Borges, P.T.; Frazão, C.; Teixeira, M. How superoxide reductases and flavodiiron proteins combat oxidative stress in anaerobes. Free Radic. Biol. Med. 2019, 140, 36-60. [CrossRef]

78. Nóbrega, C.S.; Pauleta, S.R. Reduction of hydrogen peroxide in gram-negative bacteria-Bacterial peroxidases. Adv. Microb. Physiol. 2019, 74, 415-464. [CrossRef]

79. Soito, L.; Williamson, C.; Knutson, S.T.; Fetrow, J.S.; Poole, L.B.; Nelson, K.J. PREX: PeroxiRedoxin classification indEX, a database of subfamily assignments across the diverse peroxiredoxin family. Nucleic Acids Res. 2010, 39, D332-D337. [CrossRef]

80. Maaty, W.S.; Wiedenheft, B.; Tarlykov, P.; Schaff, N.; Heinemann, J.; Robison-Cox, J.; Valenzuela, J.; Dougherty, A.; Blum, P.; Lawrence, C.M.; et al. Something Old, Something New, Something Borrowed; How the Thermoacidophilic Archaeon Sulfolobus solfataricus Responds to Oxidative Stress. PLoS ONE 2009, 4, e6964. [CrossRef]

81. Poynton, R.A.; Hampton, M.B. Peroxiredoxins as biomarkers of oxidative stress. Biochim. Biophys. Acta (BBA) Gen. Subj. 2014, 1840, 906-912. [CrossRef]

82. Jeong, W.; Cha, M.-K.; Kim, I.-H. Thioredoxin-dependent hydroperoxide peroxidase activity of bacterioferritin comigratory protein (BCP) as a new member of the thiol-specific antioxidant protein (TSA)/alkyl hydroperoxide peroxidase C (AhpC) family. J. Biol. Chem. 2000, 275, 2924-2930. [CrossRef] [PubMed]

83. Wakita, M.; Masuda, S.; Motohashi, K.; Hisabori, T.; Ohta, H.; Takamiya, K.-I. The Significance of Type II and PrxQ Peroxiredoxins for Antioxidative Stress Response in the Purple Bacterium Rhodobacter sphaeroides. J. Biol. Chem. 2007, 282, 27792-27801. [CrossRef] [PubMed]

84. Clarke, D.; Mackay, C.L.; Campopiano, D.J.; Langridge-Smith, P.; Brown, A.R. Interrogating the Molecular Details of the Peroxiredoxin Activity of the Escherichia coli Bacterioferritin Comigratory Protein Using High-Resolution Mass Spectrometry. Biochemistry 2009, 48, 3904-3914. [CrossRef]

85. Hall, A.; Nelson, K.; Poole, L.B.; Karplus, P.A. Structure-based Insights into the Catalytic Power and Conformational Dexterity of Peroxiredoxins. Antioxid. Redox Signal. 2011, 15, 795-815. [CrossRef] [PubMed]

86. Nelson, K.J.; Knutson, S.T.; Soito, L.; Klomsiri, C.; Poole, L.B.; Fetrow, J.S. Analysis of the peroxiredoxin family: Using active-site structure and sequence information for global classification and residue analysis. Proteins Struct. Funct. Bioinform. 2011, 79, 947-964. [CrossRef] [PubMed]

87. Rhee, S.G. Overview on Peroxiredoxin. Mol. Cells 2016, 39, 1-5. [CrossRef]

88. Braida, W.; Ong, S.K. Decomposition of Nitrite under Various $\mathrm{pH}$ and Aeration Conditions. Water Air Soil Pollut. 2000, 118, 13-26. [CrossRef]

89. Winterbourn, C.C. Biological chemistry of superoxide radicals. ChemTexts 2020, 6, 1-13. [CrossRef]

90. Parimelzaghan, A.; Anbarasu, A.; Ramaiah, S. Gene Network Analysis of Metallo Beta Lactamase Family Proteins Indicates the Role of Gene Partners in Antibiotic Resistance and Reveals Important Drug Targets. J. Cell. Biochem. 2016, 117, 1330-1339. [CrossRef]

91. Panyushkina, A.E.; Matyushkina, D.; Pobeguts, O. Understanding Stress Response to High-Arsenic Gold-Bearing Sulfide Concentrate in Extremely Metal-Resistant Acidophile Sulfobacillus thermotolerans. Microorganisms 2020, 8, 1076. [CrossRef]

92. Walsh, T.R.; Toleman, M.A.; Poirel, L.; Nordmann, P. Metallo- $\beta$-Lactamases: The Quiet before the Storm? Clin. Microbiol. Rev. 2005, 18, 306-325. [CrossRef] [PubMed] 
93. Gerdes, K.; Maisonneuve, E. Bacterial Persistence and Toxin-Antitoxin Loci. Annu. Rev. Microbiol. 2012, 66, 103-123. [CrossRef]

94. Fléchard, M.; Gilot, P. Physiological impact of transposable elements encoding DDE transposases in the environmental adaptation of Streptococcus agalactiae. Microbiology 2014, 160, 1298-1315. [CrossRef] [PubMed]

95. Wright, M.S.; Mountain, S.; Beeri, K.; Adams, M.D. Assessment of Insertion Sequence Mobilization as an Adaptive Response to Oxidative Stress in Acinetobacter baumannii Using IS-seq. J. Bacteriol. 2017, 199. [CrossRef] [PubMed]

96. Hansen, S.; Vulić, M.; Min, J.; Yen, T.-J.; Schumacher, M.A.; Brennan, R.G.; Lewis, K. Regulation of the Escherichia coli HipBA toxin-antitoxin system by proteolysis. PLoS ONE 2012, 7, e39185. [CrossRef]

97. Virtanen, P.; Wäneskog, M.; Koskiniemi, S. Class II contact-dependent growth inhibition (CDI) systems allow for broad-range cross-species toxin delivery within the Enterobacteriaceae family. Mol. Microbiol. 2019, 111, 1109-1125. [CrossRef] [PubMed]

98. Cañas-Duarte, S.J.; Perez-Lopez, M.I.; Herrfurth, C.; Sun, L.; Contreras, L.M.; Feussner, I.; Leidy, C.; Riaño-Pachón, D.M.; Restrepo, S.; Pedraza, J.M. An integrative approach points to membrane composition as a key factor in E. coli persistence. bioRxiv 2020. [CrossRef]

99. Johnson, L.A.; Hug, L.A. Distribution of reactive oxygen species defense mechanisms across domain bacteria. Free Radic. Biol. Med. 2019, 140, 93-102. [CrossRef]

100. Christel, S.; Herold, M.; Bellenberg, S.; El Hajjami, M.; Buetti-Dinh, A.; Pivkin, I.V.; Sand, W.; Wilmes, P.; Poetsch, A.; Dopson, M. Multi-omics Reveals the Lifestyle of the Acidophilic, Mineral-Oxidizing Model Species Leptospirillum ferriphilum T. Appl. Environ. Microbiol. 2017, 84, e02091-17. [CrossRef]

101. Kojima, H.; Watanabe, T.; Fukui, M. Sulfuricaulis limicola gen. nov., sp. nov., a sulfur oxidizer isolated from a lake. Int. J. Syst. Evol. Microbiol. 2016, 66, 266-270. [CrossRef]

102. Terrón-González, L.; Martín-Cabello, G.; Ferrer, M.; Santero, E. Functional Metagenomics of a Biostimulated Petroleum-Contaminated Soil Reveals an Extraordinary Diversity of Extradiol Dioxygenases. Appl. Environ. Microbiol. 2016, 82, 2467-2478. [CrossRef] [PubMed]

103. Jang, G.I.; Hwang, C.Y.; Cho, B.C. Nitratireductor aquimarinus sp. nov., isolated from a culture of the diatom Skeletonema costatum, and emended description of the genus Nitratireductor. Int. J. Syst. Evol. Microbiol. 2011, 61, 2676-2681. [CrossRef] [PubMed]

104. Ou, D.; Huang, H.; Bai, R.; Li, Q.; Wang, Y.; Yin, Y. Nitratireductor aestuarii sp. nov., a marine alphaproteobacterium isolated from an estuary. Int. J. Syst. Evol. Microbiol. 2017, 67, 1637-1642. [CrossRef] [PubMed]

105. Lemire, J.; AlHasawi, A.; Appanna, V.D.; Tharmalingam, S. Metabolic defence against oxidative stress: The road less travelled so far. J. Appl. Microbiol. 2017, 123, 798-809. [CrossRef]

106. Cosgrove, K.; Coutts, G.; Jonsson, I.-M.; Tarkowski, A.; Kokai-Kun, J.F.; Mond, J.J.; Foster, S.J. Catalase (KatA) and Alkyl Hydroperoxide Reductase (AhpC) Have Compensatory Roles in Peroxide Stress Resistance and Are Required for Survival, Persistence, and Nasal Colonization in Staphylococcus aureus. J. Bacteriol. 2006, 189, 1025-1035. [CrossRef]

107. Pagán-Ramos, E.; Song, J.; McFalone, M.; Mudd, M.H.; Deretic, V. Oxidative Stress Response and Characterization of the oxyR-ahpC and furA-katG Loci in Mycobacterium marinum. J. Bacteriol. 1998, 180, 4856-4864. [CrossRef]

108. Tralau, T.; Vuilleumier, S.; Thibault, C.; Campbell, B.J.; Hart, C.A.; Kertesz, M.A. Transcriptomic Analysis of the Sulfate Starvation Response of Pseudomonas aeruginosa. J. Bacteriol. 2007, 189, 6743-6750. [CrossRef]

109. Park, C.; Shin, B.; Park, W. Protective Role of Bacterial Alkanesulfonate Monooxygenase under Oxidative Stress. Appl. Environ. Microbiol. 2020, 86. [CrossRef]

110. Meyer, Y.; Buchanan, B.B.; Vignols, F.; Reichheld, J.-P. Thioredoxins and Glutaredoxins: Unifying Elements in Redox Biology. Annu. Rev. Genet. 2009, 43, 335-367. [CrossRef]

111. Zeller, T.; Klug, G. Thioredoxins in bacteria: Functions in oxidative stress response and regulation of thioredoxin genes. Naturwissenschaften 2006, 93, 259-266. [CrossRef]

112. D'Autréaux, B.; Toledano, M.B. ROS as signalling molecules: Mechanisms that generate specificity in ROS homeostasis. Nat. Rev. Mol. Cell Biol. 2007, 8, 813-824. [CrossRef] [PubMed]

113. Hammel, K.E.; Cornwell, K.L.; Buchanan, B.B. Ferredoxin/flavoprotein-linked pathway for the reduction of thioredoxin. Proc. Natl. Acad. Sci. USA 1983, 80, 3681-3685. [CrossRef] [PubMed] 
114. Kashima, Y. Alkyl Hydroperoxide Reductase Dependent on Thioredoxin-Like Protein from Pyrococcus horikoshii. J. Biochem. 2003, 134, 25-29. [CrossRef] [PubMed]

115. Sarin, R.; Sharma, Y.D. Thioredoxin system in obligate anaerobe Desulfovibrio desulfuricans: Identification and characterization of a novel thioredoxin 2. Gene 2006, 376, 107-115. [CrossRef]

116. Hernandez, H.; Jaquez, O.A.; Hamill, M.J.; Elliott, S.J.; Drennan, C.L. Thioredoxin Reductase from Thermoplasma acidophilum: A New Twist on Redox Regulationt,ł. Biochemistry 2008, 47, 9728-9737. [CrossRef]

117. Hosoya-Matsuda, N.; Inoue, K.; Hisabori, T. Roles of Thioredoxins in the Obligate Anaerobic Green Sulfur Photosynthetic Bacterium Chlorobaculum tepidum. Mol. Plant 2009, 2, 336-343. [CrossRef]

118. Pieulle, L.; Stocker, P.; Vinay, M.; Nouailler, M.; Vita, N.; Brasseur, G.; Garcin, E.B.; Sebban-Kreuzer, C.; Dolla, A. Study of the Thiol/Disulfide Redox Systems of the Anaerobe Desulfovibrio vulgaris Points Out Pyruvate:Ferredoxin Oxidoreductase as a New Target for Thioredoxin 1. J. Biol. Chem. 2011, 286, 7812-7821. [CrossRef]

119. McCarver, A.C.; Lessner, D.J. Molecular characterization of the thioredoxin system from Methanosarcina acetivorans. FEBS J. 2014, 281, 4598-4611. [CrossRef]

120. Norambuena, J.; Flores, R.; Cardenas, J.P.; Quatrini, R.; Chávez, R.; Levicán, G. Thiol/Disulfide System Plays a Crucial Role in Redox Protection in the Acidophilic Iron-Oxidizing Bacterium Leptospirillum ferriphilum. PLOS ONE 2012, 7, e44576. [CrossRef]

121. Cha, M.-K.; Kim, H.-K.; Kim, I.-H.; Johnston, J.A.; Wang, L.-M.; Hanson, E.P.; Sun, X.-J.; White, M.F.; Oakes, S.A.; Pierce, J.H.; et al. Thioredoxin-linked "Thiol Peroxidase" from Periplasmic Space of Escherichia coli. J. Biol. Chem. 1995, 270, 28635-28641. [CrossRef]

122. Atack, J.M.; Harvey, P.; Jones, M.A.; Kelly, D.J. The Campylobacter jejuni Thiol Peroxidases Tpx and Bcp Both Contribute to Aerotolerance and Peroxide-Mediated Stress Resistance but Have Distinct Substrate Specificities. J. Bacteriol. 2008, 190, 5279-5290. [CrossRef] [PubMed]

123. Ruddock, L.W.; Klappa, P. Oxidative stress: Protein folding with a novel redox switch. Curr. Biol. 1999, 9, R400-R402. [CrossRef]

124. Carmel-Harel, O.; Storz, G. Roles of the Glutathione- and Thioredoxin-Dependent Reduction Systems in the Escherichia coli and Saccharomyces cerevisiae Responses to Oxidative Stress. Annu. Rev. Microbiol. 2000, 54, 439-461. [CrossRef] [PubMed]

125. Ritz, D.; Beckwith, J. Roles of Thiol-Redox Pathways in Bacteria. Annu. Rev. Microbiol. 2001, 55, 21-48. [CrossRef] [PubMed]

126. Scott, M.D.; Meshnick, S.R.; Eaton, J.W. Superoxide dismutase-rich bacteria. Paradoxical increase in oxidant toxicity. J. Biol. Chem. 1987, 262, 3640-3645.

Publisher's Note: MDPI stays neutral with regard to jurisdictional claims in published maps and institutional affiliations.

(C) 2020 by the authors. Licensee MDPI, Basel, Switzerland. This article is an open access article distributed under the terms and conditions of the Creative Commons Attribution (CC BY) license (http://creativecommons.org/licenses/by/4.0/). 